\title{
van Hiele instructional package for vocational school students' spatial reasoning
}

\author{
Evvy Lusyana ${ }^{1}$, Wahyu Setyaningrum ${ }^{2}$
}

\begin{abstract}
Abstrak: Artikel ini membahas kepraktisan dan keefektifan perangkat pembelajaran matematika sekolah menengah kejuruan (SMK) berbasis teori van Hiele dan berorientasi pada penalaran spasial. Perangkat pembelajaran berupa rencana pelaksanaan pembelajaran (RPP) dan lembar kegiatan siswa (LKS). Pengembangan perangkat pembelajaran dalam penelitian ini menggunakan model pengembangan ADDIE. Instrumen pengumpulan data terdiri dari lembar observasi keterlaksanaaan pembelajaran, lembar penilaian kepraktisan dari guru dan siswa, dan tes penalaran spasial. Subjek uji coba perangkat pembelajaran adalah 106 siswa dari tiga kelas di SMKN 2 Ngawi. Hasil penelitian menunjukkan bahwa perangkat pembelajaran memenuhi kriteria praktis. Hal ini dapat dilihat dari respon guru dan siswa yang menyatakan bahwa perangkat dapat digunakan dalam pembelajaran di kelas. Selain itu, perangkat yang dikembangkan juga efektif dinilai dari persentase ketuntasan kemampuan penalaran spasial siswa mencapai $82 \%$ setelah menggunakan perangkat pembejalaran yang dikembangkan. Penelitian ini menyimpulkan bahwa perangkat pembelajaran yang dikembangkan dapat digunakan oleh guru untuk mendukung siswa berpikir spasial.
\end{abstract}

Kata kunci: Perangkat Pembelajaran; Teori van Hiele; Penalaran Spasial

\begin{abstract}
This paper discusses the practicality and effectiveness of mathematics instructional package for vocational school based on van Hiele theory and oriented to spatial reasoning. The instructional package was developed through ADDIE's model. The research instruments consisted of observation sheet, practicality assessment sheets from teachers and students, and spatial reasoning test. The tryout involved 106 students from three classes in SMKN 2 Ngawi. The result showed that the instructional package is practical to use referring to the teacher's and students' responses. It was also effective since $82 \%$ of students passed the spatial reasoning test. The research
\end{abstract}

\footnotetext{
${ }^{1}$ SMK Muhammadiyah 2 Ngawi, Jawa Timur, Indonesia, evvy.himalaya@gmail.com

${ }^{2}$ Universitas Negeri Yogyakarta, Yogyakarta, Indonesia
} 
concludes that the package can be utilized to support students' spatial reasoning.

Keywords: Instructional Package; van Hiele Theory; Spatial Reasoning

\section{A. Introduction}

Geometry is essential material to be learned in mathematics (NCTM, 2000; Abdullah \& Zakaria, 2013). The standard of learning geometry for grade 9-12 mentions that all students should be able to apply the transformation and use symmetry to analyze a mathematical situation. Students of grade 11-12, in particular, are expected to be able to use visualization, spatial reasoning, and modeling to solve the problem (NCTM, 2000). In the standard curriculum of geometry, spatial reasoning has a close relationship with geometry learning and needs to be facilitated in the classroom.

Some researchers (Clements \& Batistta, 1992; May \& Smith, 1998; Kondor, 2007; Bosnyak \& Kondor, 2008; Sarama \& Clements, 2009; van de Walle, Karp, \& Bay-Williams, 2010) used different terms to call spatial reasoning such as spatial intelligence, spatial ability, spatial thinking, and spatial sense. In this research, we use the term spatial reasoning. Spatial reasoning is a set of cognitive processes that utilize the basic knowledge of the shape, position, and transformation of two-dimensional and threedimensional objects, capable of finding the relation of those objects and manipulating the visible information to solve related problems. Based on theory (Clements \& Batistta, 1992; Maier, 1997; Sarama \& Clement, 2009) spatial reasoning has five components. Every indicator has its characteristic. Each question represented every indicator of spatial reasoning, namely: 1) spatial orientation; 2) spatial visualization; 3) mental rotation; 4) spatial relation; 5) spatial perception In spatial reasoning, students are required to use intuition in determining the solution of a problem and do little calculation. So that students are more skilled and quick in thinking.

Many researches (e.g., Unal, Jakubowski \& Corey, 2009; Bruce \& Hawes, 2014; Fajri, Johar, \& Ikhsan, 2016) agreed with that spatial reasoning has a close relationship with geometry and must be facilitated in the learning. Prior researches of spatial reasoning have concluded that: it has a relationship with geometry and can be used to construct an understanding of geometry (NCTM, 2000; Unal, Jakubowski, \& Corey, 2009; Gunderson, Ramirez, Beilock, \& Levine, 2012; Bruce \& Hawes, 
2014); it helps in solving problems (Bruce \& Hawes, 2014; Yarmohammadian, 2014); it predicts ability and achievement in mathematics; it makes success in science, technology, architecture, and cartography; it can predict career (e.g., Pruden, Levine, \& Huttenlocher, 2011; Yilmaz, 2012; Mulligan, 2015). In this case, the spatial reasoning must be developed by every student, need to be facilitated, and improved.

Prior researches (e.g., Erdogan \& Durmus, 2009; Abdullah \& Zakaria, 2013; Bansilal \& Naidoo, 2012) found that van Hiele theory supports the students improving spatial reasoning and learning geometry transformation refer to their respective thinking level. There are five learning phases according to van Hiele theory: 1) information, in this phases teacher and students, have to make little discussion; 2) guided orientation, students activities to understand the topic through simple problems; 3 ) explication, students try to give explanation about topic; 4) free orientation, students practice to solve complex problem; 5) integration, students make conclusion related to whole topic (Clements \& Batistta, 1992; Tambunan, 2006; Kondor, 2007; van de Walle, Karp, \& BayWilliams, 2010). Also, Howes and Howes (2015) argued that students begin to understand geometry through direct interaction with their physical world, then they can make the world becomes a big classroom so students can touch, and manipulate shapes develop spatial reasoning skill.

However, there are still many teachers who rule out spatial reasoning, since they only assume that spatial reasoning does not significantly affect students' score (Moss, Hawes, Naqvi, \& Caswell, 2015). As a result, teachers relied much on the textbook, delivered mathematical concepts directly to students and lack of meaningful activities and real context for students. According to French (2004), the abstract mathematical learning, which starts with introducing the formula, is not a good way to improve students' abilities. Learning mathematics will work better when it starts with something that is easily understood by students, such as introducing real examples that students can easily find so that they will have a vision of the material learned. Moreover, teachers who teach mathematics in the engineering class at SMKN 2 Ngawi explained that there were no learning activities that specifically designed to facilitate the development of students' spatial reasoning. Based on the interview with students in SMKN 2 Ngawi, they learned mathematics from textbooks and general student's worksheets which published by general company publisher. The textbooks and worksheets did not facilitate spatial reasoning. The students were also challenging to understand the explanations in mathematics textbooks and preferred slow learning. 
Based on these facts, they needed other learning resources that make them easier to learn according to the thinking level and facilitate spatial reasoning.

Referring to prior researches (e.g., Pruden, Levine, \& Huttenlocher 2011; Yilmaz, 2012; Mulligan, 2015), learning activities that facilitate spatial reasoning are very useful for students both at school and work which have a connection with STEM (Science, Technology, Engineering, Mathematics). Therefore, it is necessary to have activities in class that designed to facilitate students' spatial reasoning so that they can succeed in various fields. In fact, the learning resources for vocational students are less (Rosyida \& Jailani, 2014; Atsnan, 2016; Narendrawati, 2017) to facilitate spatial reasoning in specific. One of the learning theories that support students' mathematics learning based on their thinking level, geometric understanding, and spatial reasoning is van Hiele theory.

Many researchers (e.g., Erdogan \& Durmus, 2009; Abdullah \& Zakaria, 2013; Astuti, 2015) have developed instructional package using van Hiele theory, but only a few researchers concern on vocational school instructional package especially to facilitate spatial reasoning. Therefore, this research developed instructional package by combining the van Hiele theory and components of spatial reasoning which can be applied in geometric transformation topic. The reason for choosing geometric transformation is that it is one of the new materials in curriculum 2013 (Kemendikbud, 2016). This paper discusses the practicality and the effectiveness of the developed package.

\section{B. Methods}

The development procedure follows Analyzing, Designing, Developing, Implementing, and Evaluating stages (ADDIE; Branch, 2009). Figure 1 shows that ADDIE stages have evaluation and revision for which it supports the developed product and can be implemented to reduce problems in school. The subjects in this research were 106 students from 3 classes of grade 11 majoring engineering; 33 students of Automotive Engineering (AE) 1 class, 32 students of AE 3 class, and 32 students of Building Sketch Technique (BST) at SMKN 2 Ngawi academic year 2016/2017. The selection of research subjects was based on the theoretical studies (Pruden, Levine \& Huttenlocher, 2011; Turgut \& Yilmaz, 2012; Mulligan, 2015) that spatial thinking is essential for STEM.

In the analysis stage, we collected information about the needs, the character of students and mathematics topics. They gave insights on the problem, i.e., the limited of mathematics resource in the vocational school to improve spatial reasoning, to be solved. The next stage is to design 
lesson plans and worksheets using van Hiele theory and oriented toward students' spatial reasoning. Table 1 shows the spatial reasoning indicators.

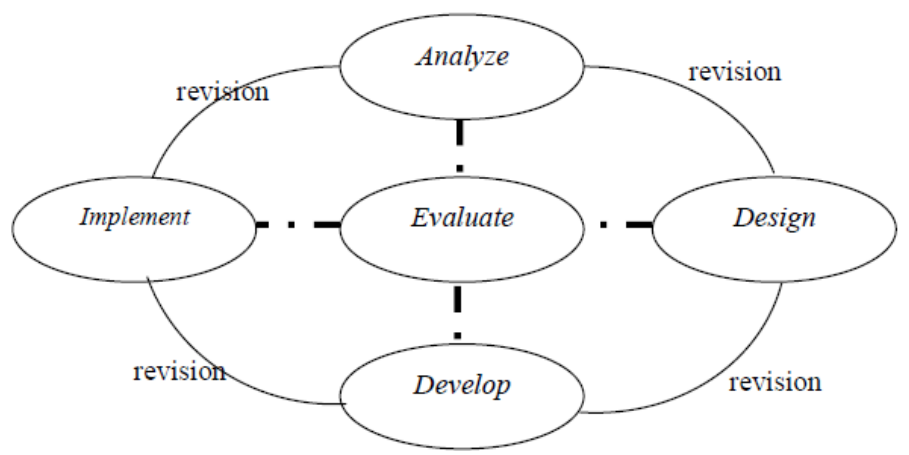

Figure 1. ADDIE's Development Procedure

The thinking levels of student was directed to geometric transformation, namely: 1 ) thinking level 0 : students are able to understand the shape of geometric objects in the Cartesian plane; 2) the thinking level 1: students are able to identify the characteristics of geometric transformation and transformed geometry; 3 ) the thinking level 2: students are able to think about the types of transformations to geometry objects, as well as the relationships and differences between the transformations performed; 4) the thinking level 3; students are able to understand the concept presented through the examples until simple proof; 5) the thinking level 4: students are able to solve complex problems. Table 2 shows the plan used in this research to facilitate spatial reasoning using van Hiele learning phases.

Table 1. The indicators of spatial reasoning

\begin{tabular}{ll}
\hline \multicolumn{1}{c}{ Indicator } & \multicolumn{1}{c}{ Ability } \\
\hline Spatial orientation & $\begin{array}{l}\text { Students are able to think and determine the } \\
\text { shape of a plane } \\
\text { Students are able to know transformation } \\
\text { shape or position of an object } \\
\text { Students are able to know transformation of a } \\
\text { plane and a solid based on its rotation } \\
\text { direction }\end{array}$ \\
Spental rotation & $\begin{array}{l}\text { Students are able to know the spatial shape or } \\
\text { relationship between parts of the plane } \\
\text { Students are able to know the parts of a plane } \\
\text { or a solid in a vertical or horizontal position }\end{array}$ \\
\hline
\end{tabular}


In the development stage, we started preparing lesson plans and worksheets followed by expert validation. Expert validation aimed to determine the feasibility and validity of the product development. We used Table 2 to design the lesson plan and student's worksheet to facilitate spatial reasoning.

Table 2. Plan for facilitating spatial reasoning

\begin{tabular}{|c|c|c|}
\hline $\begin{array}{c}\text { Spatial } \\
\text { Reasoning } \\
\text { ability }\end{array}$ & van Hiele Phases & How to Facilitate \\
\hline $\begin{array}{l}\text { Spatial } \\
\text { orientation } \\
\text { Spatial } \\
\text { visualization } \\
\text { Spatial } \\
\text { perception }\end{array}$ & $\begin{array}{l}\text { Information, guided } \\
\text { orientation, } \\
\text { explication, } \\
\text { integration } \\
\text { Levels of thinking: } 0-3\end{array}$ & $\begin{array}{l}\text { Students are directed to } \\
\text { think and determine the } \\
\text { shape of the geometry } \\
\text { object, its parts, and } \\
\text { characteristics of geometric } \\
\text { transformation }\end{array}$ \\
\hline $\begin{array}{l}\text { Spatial } \\
\text { relation }\end{array}$ & $\begin{array}{l}\text { Free orientation, } \\
\text { integration } \\
\text { Level of thinking: } 3\end{array}$ & $\begin{array}{l}\text { Students are given } \\
\text { questions, to improve their } \\
\text { understanding of geometry } \\
\text { object's shapes after } \\
\text { transformation }\end{array}$ \\
\hline $\begin{array}{l}\text { Mental } \\
\text { rotation }\end{array}$ & $\begin{array}{l}\text { Guided orientation, } \\
\text { explication, } \\
\text { integration } \\
\text { Level of thinking: } 4\end{array}$ & $\begin{array}{l}\text { Students are directed to } \\
\text { think and understand of } \\
\text { rotation's geometry object }\end{array}$ \\
\hline
\end{tabular}

After the developed product was declared feasible, then lesson plans and worksheets could be implemented in the school. The last stage of product development is to evaluate the lesson plans and worksheets that have been tested to determine the practicality and effectiveness. If the product did not fulfill the criteria of practicality and effectiveness, then lesson plans and worksheets were revised and enhanced before using in the research. Nieveen (1999) described three quality-aspects as a product quality consideration; the product must be valid, practical, and effective.

The instruments in this research were validity instrument, practicality instrument, and spatial reasoning tests for effectiveness. The practicality of the instructional package was measured by three instruments: 1) practicality sheet by teacher, the questioner consisted of 23 items to examine the appropriateness of instructional package based on van Hiele's phases to facilitate spatial reasoning and the ease of application in learning process; 2 ) student's practicality sheet, the questioner consist of 
16 items about benefits and the ease of student's worksheet; 3 ) sheet of learning observation should be $\geq 89 \%$.

Five items of spatial reasoning test measure the effectivity aspect. These test items were based on the indicators of spatial reasoning. Question 1 was to examine students' spatial orientation, so we can determine students' reasoning capability to determine the shape of a plane. Question 2 was to determine students' spatial visualization which makes students able to know transformation shape or position of an object. Question 3 was about mental rotation to determine students' reasoning capability of transforming (change) a plane and a solid based on its rotation direction. Question 4 was for spatial relation, examining students reasoning for the spatial shape or relationship between parts of the shape. Question 5 for spatial perception, examining students' ability to identify the parts of a plane or a solid in a vertical or horizontal position.

This research collected both qualitative and quantitative data. The qualitative data was perceived from the result of validation sheet, the practicality assessment by teachers and students, and the learning activity sheet. It was then converted into quantitative data. Table 3 below shows the qualitative to quantitative data conversion.

Table 3. The category of conversion from quantitative data to qualitative data

\begin{tabular}{cc}
\hline Interval & Category \\
\hline$X>\bar{x}_{i}+2 s b$ & Very good \\
$\bar{x}_{i}+0,8 s b_{i}<X \leq \bar{x}_{i}+2 s b_{i}$ & Good \\
$\bar{x}_{i}+0,4 s b_{i}<X \leq \bar{x}_{i}+0,8 s b_{i}$ & Fair \\
$\bar{x}_{i}-0,8 s b_{i}<X \leq \bar{x}_{i}+0,4 s b_{i}$ & Poor \\
$X \leq \bar{x}_{i}-0,8 s b_{i}$ & Very poor \\
\hline
\end{tabular}

Notes:

X : empirical score

$\overline{\bar{x}_{i}} \quad:$ ideal mean score $=\frac{1}{2}(\max$ score + min score $)$

$\sqrt{s b_{i}} \quad:$ Standart deviation $=\frac{1}{6}(\max$ score - min score $)$

(Maximum ideal score $=$ item $区$ highest score )

(Minimum ideal score $=$ item $\varnothing$ lowest score)

Table 3 is the reference for criteria of validity and practicality of instructional package. The effectiveness criterion refers to the standard of 
minimum completeness. Product development considered practical if the practicality score of each judgment of instructional package in the practical category, as well as the implementation of learning activities, reached $90 \%$. While on the aspect of effectiveness, product development is effective if at least $80 \%$ have a minimum score in the standard of minimum completeness for spatial reasoning test.

\section{Findings and Discussion}

This research aimed to develop an instructional package which comprises lesson plans and students' worksheets based on van Hiele theory and oriented to spatial reasoning. The instructional package was developed to facilitate spatial orientation, spatial visualization, and spatial perception by providing an illustration or example of the application of transformation principle that occurs around students and on vocational materials. Then the spatial relation component can be facilitated through the provision of direct or written questions. Such activities can assist students in sharpening their thinking to know and determine the shape of the plane, its parts, and the transformation of a geometry plane.

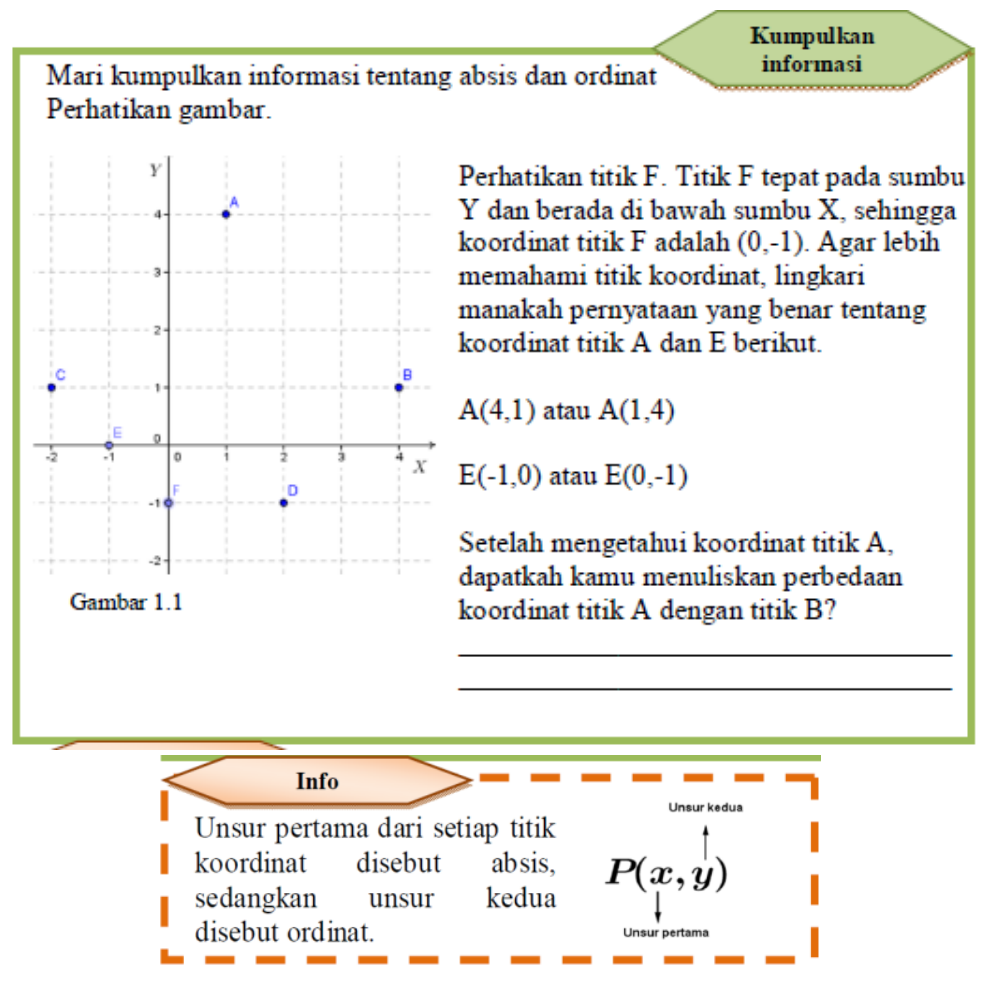




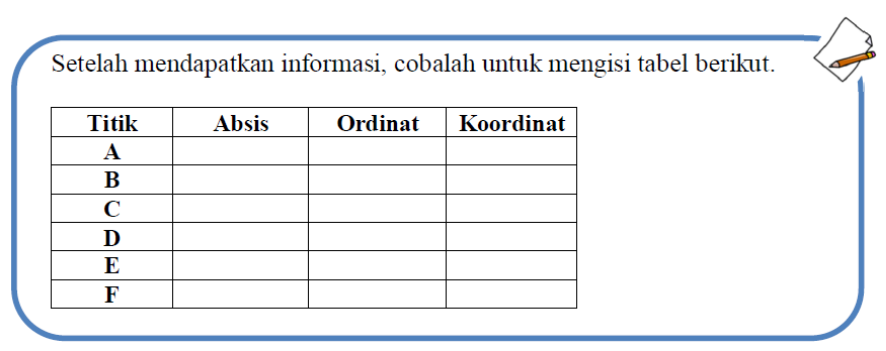

Figure 2. Information phase

The developed worksheets have general information and illustrations related to the topics with the aim of helping students to reason spatially. Also, it provided exercises of spatial reasoning and geometric transformation. Based on the interviews with students that many students of vocational school preferred the teacher to explain the material and gives examples or ask students to solve the mathematical problems with small group discussion. Moreover, vocational school students preferred worksheet that already provided the formula. In the developed worksheets, we presented some formulas, examples, and exercises that could be solved through discussions with classmates or small group discussions.

For example, in the worksheet (Figure 2) we placed information to remind students how to read and express in the Cartesian field. Here, there are no specific activities for explication phase, because sometimes explication phase was including in the other phase activities. After guided orientation activity, students have to express or present their result. From Figure 2, students could remember how to express coordinate information, try to build their spatial orientation from the figure, and then try to express in the blank table. On the first stage of van Hiele theory, the teachers should give information or simple questions to remind students before asking students to solve the mathematical problem. Figure 3 is the examples of applying guided orientation.

In the worksheet (Figure 3.a and 3.b), we tried to apply guided orientation and integration phase to build student's understanding, spatial visualization, and spatial perception. From those, students learn to determine the shape of the geometry object, its parts, and characteristics of geometric transformation.

In Figure 4, students learned how to solve problem mathematically. Since students in vocational school preferred worksheet that already provided the formula, we put the example to build their understanding on the formulas. Figure 5 is one of the students' general books in their school. Most student's textbooks did not have specific activities to build 
their understanding of geometry (transformational geometry) moreover spatial reasoning.

The implementation of lesson plans and students' worksheets aimed to determine the practicality and effectiveness of instructional package. The test of products was conducted at SMKN 2 Ngawi with 106 students. The learning activities were guided by lesson plans and worksheets which had been designed. We had provided the worksheets for each student. In the learning process, students were not asked to always sit in groups, but to discuss the provided problems on the worksheet with the guidance of teachers in the classroom. This part discussed the implementation of the instructional package in four meetings. The following are reviews of each meeting.

Edo baru datang dan berdiri dekat pintu kelas. Dia melihat Novi, Bella dan Wisnu berkumpul. Edo berjalan mendekat ke arah meja Wisnu, dan mendengar mereka sedang membahas tentang bakti sosial yang akan diadakan oleh OSIS. Tidak lama setelah itu bel tanda masuk berbunyi, Edo dan yang lain berjalan menuju tempat duduk masing-masing.

\section{Petunjuk}

Posisi Edo dapat dimisalkan sebagai titik A, B, dan C. Titik A adalah posisi Edo berdiri di dekat pintu kelas, B adalah posisi Edo di dekat meja Wisnu, dan $\mathrm{C}$ adalah posisi Edo duduk di kursinya. Lukislah titik $\mathrm{A}(2,2), \mathrm{B}(7,7)$ dan $\mathrm{C}(7,2)$ pada bidang kartesius berikut.

(a)

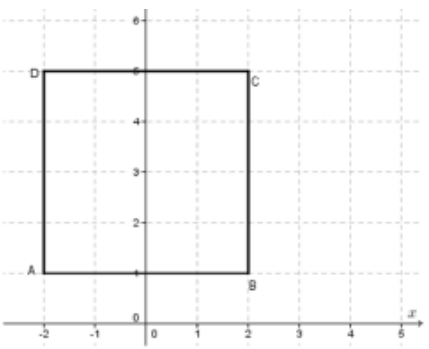

(1)

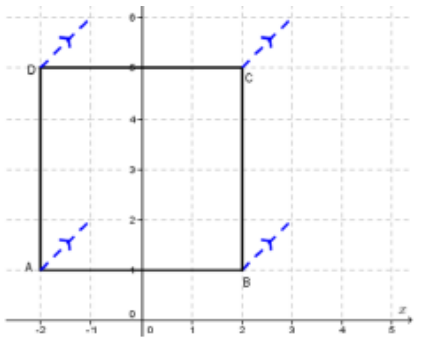

(2)

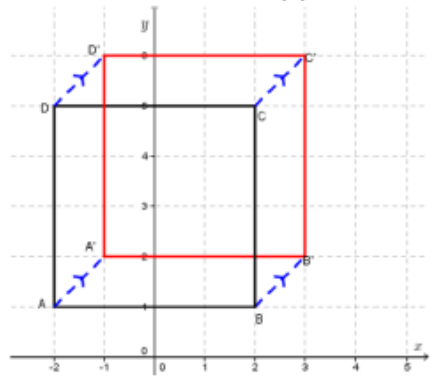


$\mathrm{ABCD}$ adalah benda asli, sedangkan $\mathrm{A}^{\prime} \mathrm{B}$ ' $\mathrm{C}$ ' $\mathrm{D}$ ' adalah bayangan hasil perpindahan dari

$A B C D$. Tuliskan kesamaan $A^{\prime} B^{\prime} C^{\prime} D^{\prime}$ 'dengan benda aslinya.

(b)

Figure 3. Guided orientation and integration phase

We applied developed worksheet four times during research. The first meeting was held in AE 3 class and AE 1 class. In general, learning ran, but it did not meet the expectation regarding the use of worksheets. For this condition, we tried to discuss this problem with teachers to find the solution. Then we tried applying the solution in BST 1 class. In the second meeting up to the fourth meeting, although not precisely similar to research design, learning using developed worksheets started to work. The topics during research are 1) translation for the first meeting, 2) reflection in the second meeting; 3 ) rotation for the third meeting; and 4) dilation for the fourth meeting. Spatial orientation, visualization, spatial perception and spatial relation can be built while learning all the topics except for mental rotation which can only be built upon rotation.

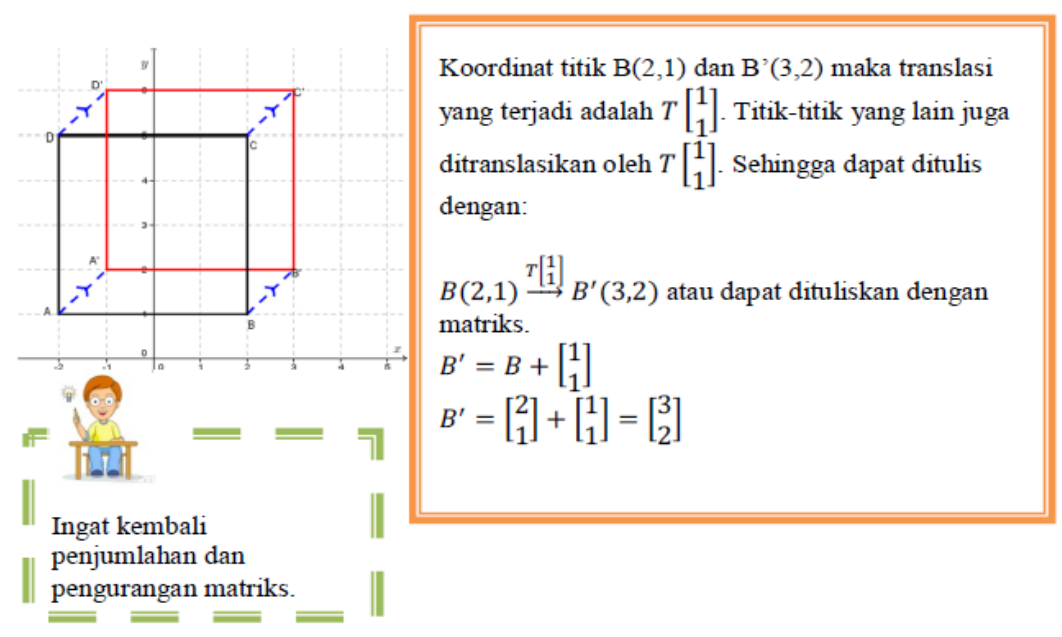




\section{Asah kemampuan}

1. Tentukan bayangan garis $\mathrm{KL}$, dengan titik $\mathrm{K}(2,3)$ dan $\mathrm{L}(1,4)$ oleh translasi $T\left[\begin{array}{c}-2 \\ 4\end{array}\right]$.

2. $P(-5,7), Q(3,-4)$ dan $R(-6,-8)$ adalah titik-titik segitiga $P Q R$. Segitiga $P Q R$ ditranslasikan 4 satuan ke kanan dan 2 satuan ke bawah.

a. Tentukan titik koordinat dari $\mathrm{P}^{\prime}, \mathrm{Q}^{\prime}$, dan $\mathrm{R}^{\prime}$.

b. Lukislah segitiga PQR dan bayangan hasil translasinya.

3. Tentukan komponen translasi dari gambar berikut.

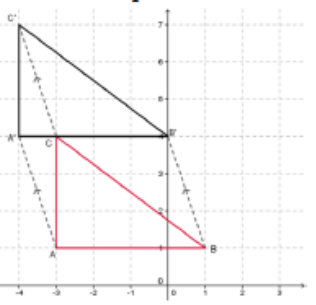

Figure 4. Free orientation phase

4. Dilatasi

Dilatasi adalah transformasi yang mengubah ukuran tetapi tidak mengubah bentuk suatu bangun. Bayangan titik $P(x, y)$ dilatasi dengan faktor skala $k$ dan pusat $O(0,0)$ adalah sebagai berikut.

$$
P(x, y) \rightarrow P^{\prime}(k x, k y)
$$

dalam bentuk perkalian matriks ditulis,

$$
\left(\begin{array}{l}
x^{\prime} \\
y^{\prime}
\end{array}\right)=\left(\begin{array}{ll}
k & 0 \\
0 & k
\end{array}\right)\left(\begin{array}{l}
x \\
y
\end{array}\right)
$$

Bayangan titik $P(x, y)$ oleh dilatasi dengan faktor skala $k$ pusat $(a, b)$ adalah sebagai berikut.

$$
P(x, y) \rightarrow P^{\prime}(a+k(x-a), b+k(y-b))
$$

Figure 5. Student's general textbook

Generally, for the first meeting in three classes, students were not familiar with the developed worksheets, so it took quite a long time. During the learning, many students did not discuss with other students but trying to solve their own "Asah Kemampuan" activities. Many students still could not follow the learning using worksheets. Consequently, the exercise activities could not be implemented in the class and made as homework. Moreover, the teacher had no chance to ask the student to present their conclusions and reflection. However, it 
turned out that some students have written their conclusions on the worksheet.

At the second meetings in $\mathrm{AE} 3$ and $\mathrm{AE} 1$ classes, the learning activities had already started based on the plan, but there were still some unfulfilled activities such as solving exercise activities and teacher still appointed students to deliver their solution. In other class, students began to be active in the learning process, and some students bravely asked related problems in the worksheets. Then, students made illustrations by moving their hands to ease thinking about transformation. After that, students draw the transformation-plane in the provided Cartesian plane.

Based on the evaluation from two classes, students wanted the teacher to give them explanation before they started working on the worksheet. That is why at the first meeting in the BST 1 class, the teacher tried to explain, and the learning process had started by the plan. Although some students were not enthusiastic with learning using worksheet, many students were willing to be actively involved in learning and started discussions with other students. The students were active in the discussion, but no student was submitting the worked problems. In this case, the teacher appointed some students. Later, several activities such as making reflections could not be carried out since time were spent in the activities of drawing the plane in the Cartesian field and making conclusions. At the second meeting, the teacher made the problem solving as part of drawing plane so that one group solved one problem only. The drawing plane made learning more efficient, and other activities could be accomplished. When the teacher went around, the students asked questions and showed the results of their solutions. Moreover, when the teacher appointed one of the students to deliver the results, he enthusiastically wrote the results on the board.

In the third and fourth meeting in three classes, several students asked the teacher about their answers. The students still preferred to be appointed when presenting their answers in front of the class. However, some students wanted to represent their group even if not appointed by the teacher. Even though many students were active in the learning process, there were still two students who seemed silent and didn't follow the lesson. Moreover, at the fourth meeting, there were no students who respond to the other students' work presented on the whiteboard. Here is the sample of student's work.

Figure 6, Figure 7, and Figure 8 illustrate the differences in student's perception of problems presented on the student's worksheet. We put this activity in the "Asah Kemampuan." The students were asked to sketch two different right triangles in different sizes and coordinate. In Figure 6, 
student sketched two different sized triangles. Figure 7, student sketched triangles according to the task. Then, Figure 8 shows that student sketched triangles according to task and kept attention on the translation topic which student learned at that time. These differences indicate that the spatial orientation and spatial visualization still needs particular attention from the teacher.

After the learning process, evaluation began by analyzing data on the practicality and effectiveness of instructional package. Data for practicality was collected from the observation of learning and practicality examination by the teacher and students. Based on Table 3, there are two empirical scores for practicality sheet. The first empirical scores for teacher's practicality sheet must be $\overline{X>78}$ (practice category), and student's practicality sheet must be $X>54$ (practice category). Table 4 and Table 5 show the average examination scores by teacher and students.

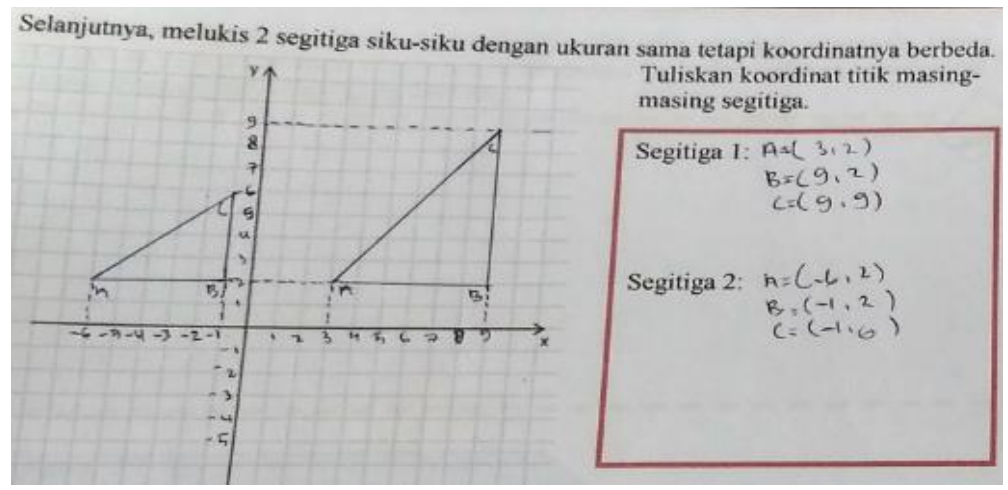

Figure 6. Student A's worksheet

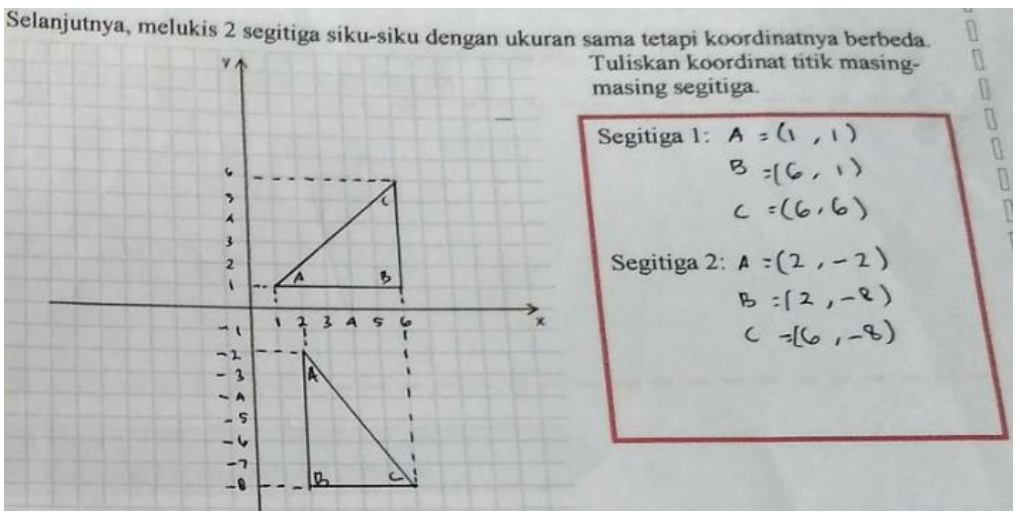

Figure 7. Student B's worksheet 


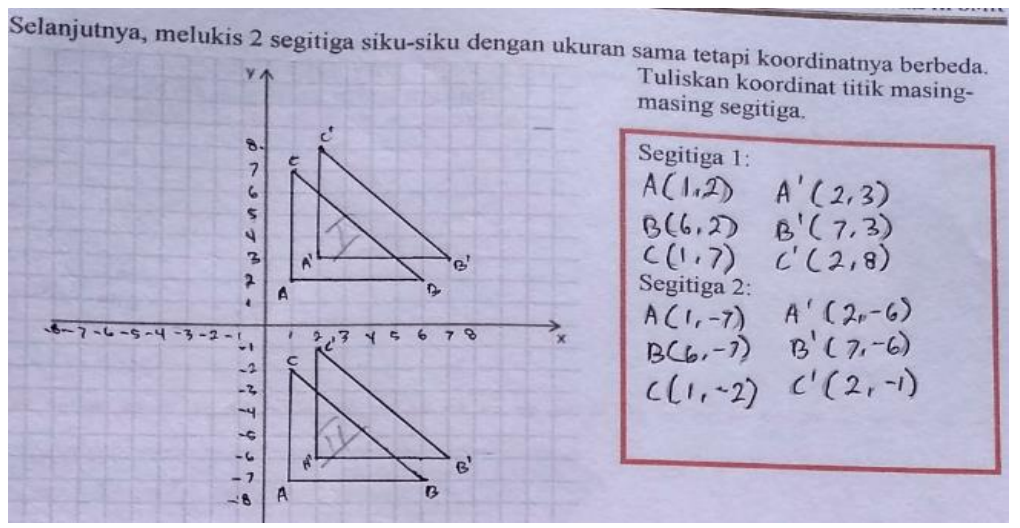

Figure 8. Student C's worksheet

Table 4 and Table 5 reveal that instructional package meets the practical category from the examination of teacher and students.

Table 4. The result of teacher's practicality sheet

\begin{tabular}{lc}
\hline \multicolumn{1}{c}{ Aspects } & Average \\
\hline Lesson plan & 33,5 \\
Student's worksheet & 37,5 \\
Learning & $\mathbf{2 6 , 5}$ \\
implementation & \\
Total average & $\mathbf{9 5 , 5}$ \\
Category & Practice \\
\hline
\end{tabular}

Table 5. The result of student's practicality sheet

\begin{tabular}{lcc}
\hline \multicolumn{1}{c}{ Class } & Average Score & Category \\
\hline AE1 & 61,4 & Practical \\
AE 3 & 58,3 & Practical \\
BST & 60,5 & Practical \\
\hline
\end{tabular}

The third practicality instrument is learning observation sheet. It is based on the activity steps in the lesson plan. Table 6 shows the result of observation data.

Table 6. The Percentage of learning

\section{Percentages (\%)}

\begin{tabular}{ccccccc} 
Meeting & \multicolumn{2}{c}{ AE 1 } & \multicolumn{2}{c}{ AE 3 } & \multicolumn{2}{c}{ BST } \\
& Teacher & Student & Teacher & Student & Teacher & Student \\
& Act & Act & Act & Act & Act & Act \\
1 & 79 & 86 & 83 & 90 & 86 & 90 \\
2 & 100 & 93 & 88 & 86 & 97 & 93 \\
\hline
\end{tabular}




\begin{tabular}{|c|c|c|c|c|c|c|}
\hline \multirow{3}{*}{ Meeting } & \multicolumn{6}{|c|}{ Percentages (\%) } \\
\hline & \multicolumn{2}{|c|}{ AE 1} & \multicolumn{2}{|c|}{ AE 3} & \multicolumn{2}{|c|}{ BST } \\
\hline & $\begin{array}{c}\text { Teacher } \\
\text { Act }\end{array}$ & $\begin{array}{c}\text { Student } \\
\text { Act }\end{array}$ & $\begin{array}{c}\text { Teacher } \\
\text { Act }\end{array}$ & $\begin{array}{c}\text { Student } \\
\text { Act }\end{array}$ & $\begin{array}{c}\text { Teacher } \\
\text { Act }\end{array}$ & $\begin{array}{c}\text { Student } \\
\text { Act }\end{array}$ \\
\hline 3 & 100 & 93 & 100 & 93 & 97 & 93 \\
\hline 4 & 100 & 97 & 100 & 97 & 100 & 100 \\
\hline Average & 94,8 & 92 & 91,4 & 91 & 94,8 & 94 \\
\hline $\begin{array}{l}\text { Total } \\
\text { Category }\end{array}$ & \multicolumn{2}{|c|}{93,15} & \multicolumn{2}{|c|}{91,2} & \multicolumn{2}{|c|}{94,4} \\
\hline
\end{tabular}

Based on Table 6, the instructional package fulfilled the practical criteria regarding the percentage of learning activities due to the implementation $(\mathrm{t}) \geq 89 \%$. From three instruments, we conclude that instructional package is practical for learning mathematics in vocational school.

Effectiveness is examined through spatial reasoning tests. The students were given spatial reasoning tests consisting of five items of multiple-choice-questions. Multiple-choice-question is easier to use than essay since multiple choices focus on thinking and the distractor a student choice may give teacher diagnostic insight into students' difficulties (Nitko \& Brookhart, 2011). It can make students concentrate on thinking and giving quick respond to spatial reasoning test. Table 7 is the result of spatial reasoning test.

Table 7. Spatial Reasoning Test's Result

\begin{tabular}{lccc}
\hline \multirow{2}{*}{ Notes } & \multicolumn{3}{c}{ Class } \\
\cline { 2 - 4 } & AE 1 & AE 3 & BST \\
\hline Highest score & 100 & 100 & 100 \\
Lowest score & 40 & 20 & 40 \\
Average score & $\mathbf{7 8 , 9}$ & $\mathbf{7 3 , 3}$ & $\mathbf{7 8 , 8}$ \\
Total average & & $\mathbf{7 2 , 3}$ & \\
Classical percentage & $86 \%$ & $78 \%$ & $82 \%$ \\
Total percentage & & $\mathbf{8 2 \%}$ & \\
\hline
\end{tabular}

Some students get the maximum score which reveals that the student was capable of all aspects of spatial reasoning. The average score of the AE 1 class was 78.9 with the percentage of completeness was $86 \%$. The average score of the AE 3 class was 73.3 with the percentage of classical completeness was $78 \%$, while the average of BST class was 78.8 with the percentage of completeness was $82 \%$. Besides, the overall average of spatial reasoning ability was 72.3 with the percentage of spatial reasoning ability was $82 \%$. Thus, the mathematics instructional 
package (lesson plan and worksheet) developed was effective concerning students' spatial reasoning because of the percentage of spatial reasoning ability reach $X \geq 80 \%$.

Table 8. Spatial reasoning's data

\begin{tabular}{lccc}
\hline \multirow{2}{*}{\multicolumn{1}{c}{ Component }} & \multicolumn{3}{c}{ Number of Students } \\
\cline { 2 - 4 } & AE 1 & AE 3 & BST \\
\hline Spatial orientation & 26 & 31 & 27 \\
Spatial visualization & 36 & 35 & 30 \\
Mental rotation & 19 & 20 & 22 \\
Spatial relation & 33 & 32 & 30 \\
Spatial perception & 32 & 17 & 21 \\
\hline
\end{tabular}

Table 8 shows that most of the students in the three classes were capable of spatial orientation, spatial visualization, and spatial relations. As the mental rotation and spatial perception ability still needed to be facilitated.

3. Perhatikan gambar berikut.

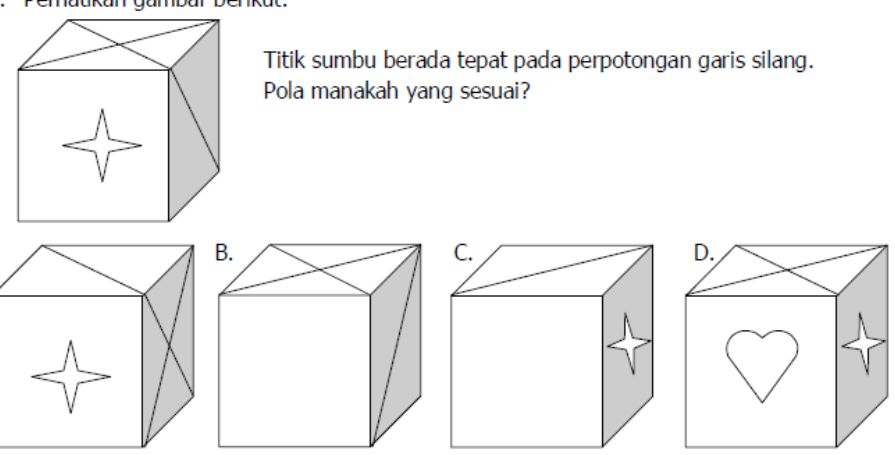

Figure 9. Spatial relation task

In the test (Figure 9), 22 of 106 students chose A. When examining the test item, and the option A was not possible as the answer to the question. It was because the "cross" on the upper side became the center of rotation so that the "cross" side would remain in its original position. However, in fact, many students chose A. It was possible because students estimated by looking at the front side that contained the "star" image unchanged, while the top side containing "cross" rotated $90^{\circ}$ in the clockwise direction. 
5. Amati gambar-gambar berpola berikut.

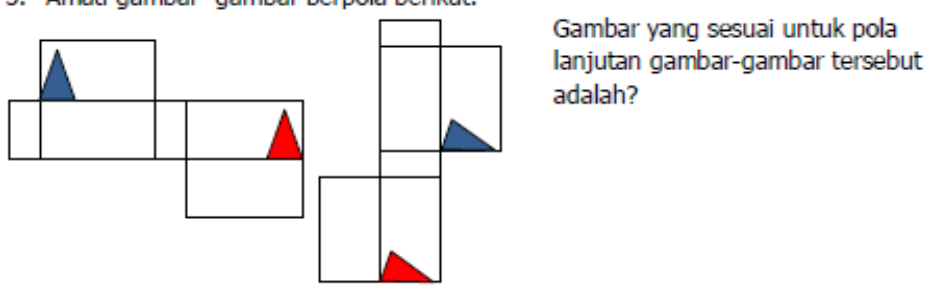

A.

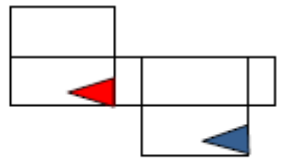

B.

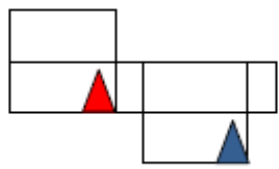

C.

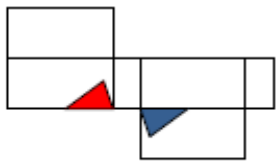

D.

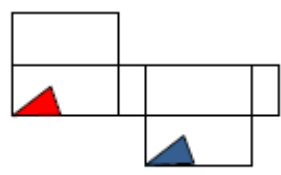

Figure 10. Spatial perception task

Figure 10 was a spatial perception test item. The students were asked to select the picture as an advanced pattern. The specified answer was D. However, 28 of 106 students chose B. They might choose B because it referred to the position of the triangle in the initial pattern.

The research found that students had difficulty distinguishing between abscissa and ordinate, square and rectangle in the Cartesian field, and the characteristic of the regular plane. After going through the learning using lesson plans and worksheets gradually, students were able to overcome these difficulties. The data also pointed out the improvement in students' thinking level. Without making calculations, students were able to describe plane displacement which indicated that the package supports students' spatial reasoning.

The findings were similar to Alattin (2016). The subjects were at the $3^{\text {rd }}$ thinking level (deduction stage). Van Hiele (van de Walle, Karp \& BayWilliams, 2010) explained that at this thinking level, students could make reasoning inductively, understand the relationship between the properties of geometric objects, and build the axioms and definitions within themselves. Therefore, the application of the package is relevant to improve the thinking level of geometry and spatial reasoning for vocational students.

In the worksheet, there were also student activities such as "Asah Kemampuan" or drawing activities to explore the ability of spatial reasoning so that students became excited, interested and enthusiastic to 
do activities in drawing the object of geometric transformation. The drawing/sketching and spatial painting activities guided by teachers are an effective way to improve spatial abilities and attract students' attention (Davis, 2015; Mohler \& Miler, 2008). In addition to the figures, instructions and explanations in the worksheets helped students to understand the topics. Student's activities guided by the teacher are one of the ways to build students' understanding (Wilder, Wilder, \& Pimm, 2011).

\section{Conclusion}

The research found that the mathematics instructional package developed based on van Hiele theory and oriented to spatial reasoning is practical and effective. The practicality refers to the fulfillment of practical criteria which was examined through three instruments, i.e., teacher's practicality sheet, student's practicality sheet and learning observation. The effectivity is perceived through spatial reasoning test which shows that the overall average of students' spatial reasoning ability was 72.3 with the percentage of spatial reasoning ability was $82 \%$. The package has several characteristics which support students' spatial reasoning, i.e. learning activities using van Hiele learning phase which consist of identifying students' initial ability in the information phase, giving examples or practice of drawing geometry in the Cartesian field in the guided orientation phase, exploring students' ability in conveying their ideas during explanation phase, completing the problems even without calculation in the free orientation phase, and identifying students' whole knowledge after learning the topics in the integration phase. Also, the worksheet provides the Cartesian field to facilitate students in spatial thinking. It also gives additional information such as formulas and the steps to induce it.

\section{Bibliography}

Abdullah, A. H, \& Zakaria, E. (2013). The effect of van Hiele's phases of learning geometry on student's degree of acquisition of van Hiele levels. Procedia-Social and Behavioral Sciences, 102(6), 251-266.

Alattin, U. (2016). Investigating $11^{\text {th }}$-grade students' van Hiele level 2 geometrical thinking. IOSR Journal of Humanities and Social Science (IOSR-JHSS), 21(12), 13-19.

Astuti, V., S. (2015). Pengembangan perangkat pembelajaran geometri berbasis teori van Hiele untuk siswa tunanetra yang menunjang hasil 
belajar siswa. Tesis Magister tidak diterbitkan, Yogyakarta: Universitas Negeri Yogyakarta.

Atsnan, M. (2016). Pengembangan perangkat pembelajaran vektor dengan pendekatan creative problem solving kelas XI SMK Teknokestan. Jurnal Riset Pendidikan Matematika, 3(1), 66-75. Doi: 10.21831/jrpm.v3il.10406.

Bansilal, S., \& Naidoo, J. (2012). Learners engaging with transformational geometry. South Africa Journal of Education, 32 (1), 26-39.

Branch, R. M. (2009). Instructional design: the ADDIE approach. New York, NY: Springer Science+Business Media.

Bruce, C. D., \& Hawes, Z. (2014). The role of 2D and 3D mental rotation in mathematics for young children: what is it? Why does it matter? And what can we do about it? ZDM Mathematics Education. Doi: 10.1007/s11858-014-0637-4.

Bosnyak, A., \& Kondor, R. N. (2008). The spatial geometry and spatial geometrical knowledge of university students majored in mathematics. Acta Dicdactica Universitatis Comenianae 8(1), 1-25.

Clements, D. H., \& Battista, M. T. (1992). Geometry and spatial reasoning. In D. A. Grouws (Ed.), Handbook of research on mathematics teaching and learning (pp. 420-464). New York, NY: Macmillan.

Davis, B. (2015). Spatial reasoning in early years: Principles, assertions, and speculations. New York, NY: Routledge, Taylor \& Francis Group.

Erdogan, T., \& Durmus, S. (2009). The effect of the instruction based on van Hiele model on the geometrical thinking levels of pre-service teacher elementary school teachers. Procedia-Social and Behavioral Sciences, $1(1), 154-159$.

Fajri, H., Johar, R., \& Ikhsan, M. (2016). Peningkatan kemampuan spasial dan self-efficacy siswa melalui model discovery learning berbasis multimedia.

Beta Jurnal Tadris Matematika, 9(2), 180-196. Doi: 10.20414/betajtm.v9i2.14

French, D. (2004). Teaching and learning geometry. New York, NY: Continuum International Publishing Group.

Gunderson, E. A., Ramirez, G., Beillock, S. L., \& Levine. (2012). The relation between spatial skill and early number knowledge: the role of the linear number line. Developmental Psychology, 48(5), 1229-1241. Doi: 10.1037/a0027433.

Howse, T. D., \& Howse, E. M. (2015). Linking the van Hiele theory to instruction. Teaching Children Mathematics, 21(5), 305-312.

Kemendikbud. (2016). Peraturan Menteri Pendidikan dan Kebudayaan RI Nomor 24 Tahun 2016, tentang Kompetensi Inti dan Kompetensi Dasar Pelajaran Pada Kurikulum 2013 pada Pendidikan Dasar dan Menengah.

Kondor, R. N. (2007). Spatial ability of engineering students. Annales Mathematicae et Informaticae, 34(1), 113-122. 
Maier, P. H. (1997). Spatial geometry and spatial ability- how to make solid geometry solid? Retrieved from http://www.fmd.uniosnabrueck.de/ebooks/gdm/paperPdf1996/Maier.

May, T. C., \& Smith, P. (1998). Spatial Ability: Handbook for teacher. Upton Park, Slough: The National Foundation for Education Research.

Mohler, J. L., \& Miller. C. L. (2008). Improving spatial ability with mentored sketching. Engineering Design Journal, 72, 19-27.

Mulligan, J. (2015). Looking within and beyond the geometry curriculum: Connecting spatial reasoning to mathematics learning. ZDM Mathematics Education, 47, 511-517. Doi: 10.1007/s11858-015-0696-1.

Narendrawati, N. (2017). Komparasi pembelajaran statistika melalui pendekatan CTL dan problem posing ditinjau dari prestasi belajar dan minat belajar matematika. Jurnal Riset Pendidikan Matematika, 4(1), 6777. Doi:10.21831/irpm.v4il.12723.

NCTM. (2000). Principles and standard for school mathematics. Reston, VA: The National Council of Teachers of Mathematics, Inc.

Nieveen, N. (1999). Prototype to reach product quality. In J. Van den Aker et al. (Eds). Design Approach and Tools in Educational Training (pp.125136). Dordrecht, NL: Kluwer Academic Publisher.

Nitko, A. J., Brookhart. S. M. (2011). Educational assessment of students. Boston, MA: Pearson.

Pruden, S. M., Levine, S. C., \& Huttenlocher, J. (2011). Children's spatial thinking: does talk about the spatial world matter? Developmental Science, 14 (6), 1417-1430. Doi: 10.1111/j.1467-7687.2011.01088-x

Rosyida, N. \& Jailani. (2014). Pengembangan modul matematika SMK bidang seni, kerajinan, dan pariwisata berbasis open-ended problem sebagai implementasi KTSP. Jurnal Riset Pendidikan Matematika, 1(1), 35-47. Doi: 10.21831/jrpm.v1i1.2662

Sarama, J. \& Clements, D. H. (2009). Early childhood mathematics education research (Learning trajectory for young children). New York, NY: Routledge Taylor and Francis Group.

Tambunan, S. M. (2006). Hubungan antara kemampuan spasial dengan prestasi belajar matematika. MAKARA, Sosial Humaniora, 10(1) , 27-32.

Turgut, M., \& Yilmaz, S. (2012). Relationship among preservice primary mathematics teachers' gender, academic success, and spatial ability. International Journal of Instruction, 5(2), 4-20.

Unal, H., Jakubowski, E., \& Corey, D. (2009). Differences in learning geometry among high and low spatial ability pre-service mathematics teacher. International Journal of Mathematical Education in Science of Technology, 40(8), 997-1012. Doi: 10.1080/00207390902912852. 
van de Walle, J. A., Karen, K. S., \& Bay-Williams, J. M., (2010). Elementary and middle school mathematics: Teaching developmentally. Boston, MA: Pearson Education, Inc.

Wilder, S. J., Wilder, T. J., \& Pimm, L.,(2010). Learning to teach mathematics in secondary school $3^{\text {rd }}$ edition. New York, NY: Routledge Falmer Tailor \& Francis Group.

Yarmohammadian, A., (2014). The relationship between spatial awareness and mathematic disorders in elementary school students with learning mathematics disorder. Psychology and Behavioral Sciences, 3, 33-40. Doi: 10.11648/j.pbs.2040301.16.

Yilmaz, H. B. (2009). On development and measurement of spatial ability. International Electronic Journal of Elementary Education, 1(2), 83-96. 